and evolution, an approach inspired by, but not identical to, the biological one. These are methods designed to cope with complex, open and dynamic environments in which predefined rules cannot properly define behaviours because of the overwhelming complexity and difficulty in describing the situation. So artificial agents have to evolve, undergo development and learn how to behave. The authors also discuss the social aspect of multiple agents, or collective intelligence. How do agents with different expertise collaboratively accomplish complex tasks of the sort seen in real society or in sports such as football? These features are considered to be critically important for a multi-agent robotics team to play football in the RoboCup (www.robocup. org). The book beautifully illustrates the development of ideas, why we need these ideas, and what the issues are.

The book focuses on artificial agents, but with a lot of inspiration from nature. This reflects the synthetic approach to understanding: by building intelligent systems we can reach a deeper understanding of intelligence in general. Biologists often criticize such approaches as not being faithful to the biological processes that inspired them. However, researchers in artificial intelligence and robotics are, for example, trying to find out how to design an aircraft inspired by bird flight, instead of replicating a bird itself. It was a huge step in engineering when bird flight was decomposed into thrust and lift, and re-implemented by fixed wings and engines to create modern aircraft. Memory, computing and learning have been similar elements of intelligence in chess machines. The grand question behind this book is the search for such essential ingredients for intelligence in an open, dynamic environment.

Hiroaki Kitano is director of Sony Computer Science Laboratories, 3-14-13 HigashiGotanda, Shinagwa, Tokyo 141-0022, Japan.

\title{
Surrealism bites back
}

\section{Sink your teeth into Jean Painlevé's nature films at an exhibition in London.}

\begin{abstract}
Martin Kemp
The success of nature documentaries on television rests on their ability to show us the wonders of the natural world. Intimate scenes such as a shimmying sea urchin embedding itself in sand no longer surprise, despite the unfamiliarity of the subject, thanks to the skill of the film-makers.

Rather more surprising is the fact that the first sustained use of film technologies to create moving images of nature's secrets occurred not within the world of professional science, but in the artistic context of surrealism.

The surrealist movement, led by Salvador Dalí, Max Ernst, André Breton and André Masson, regularly exploited biomorphic shapes in strange, dream-like contexts. The organic realm came to be populated by the unfamiliar, the uncanny and the downright sinister.

The development of film techniques resulted in a kind of 'natural surrealism'. The pioneer was Jean Painlevé, who in collaboration with Geneviève Hamon carved out a long career from 1925 to 1975 as the master of the genre. He used it to serve both science and art cinema. Painlevé is now little known, but makes a welcome appearance in the exhibition 'Surreal Things', which can be seen at the Victoria and Albert Museum in London until 22 July.

Painlevé, whose mathematician father twice became prime minister of France, was trained as biologist. He then embarked on a professional career as an actor and became involved in the anarchy of Parisian avantgarde art. His films, all short documentaries, range from soberly descriptive (although always with a strange lyricism) to overtly whimsical and ghoulish. He worked with leading experimental composers to choreograph his work - and used the music of Louis Armstrong and Duke
\end{abstract}

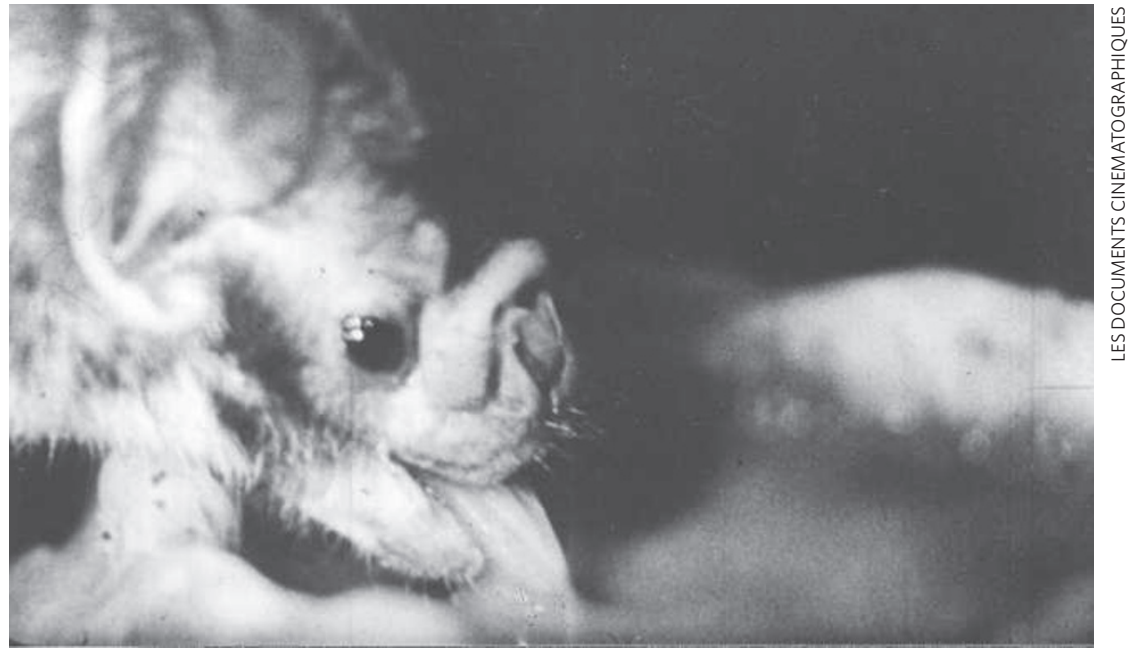

Ellington in his soundtracks.

Some of Painlevé's films, such as Sea Urchins from 1929, rely on descriptive commentaries and direct filming. The drama of these films comes from the camera work, printing and cutting. The beauty of the living and moving sea urchin is seductively captured, although the vivisection of a specimen to show its hugely efficient digestive tract induces a shiver of horror. As Painlevé claimed: "Scientific film requires study and instruction; it is not only a tool, but a grammar and an art."

Other films are self-consciously melodramatic. The Vampire, which is just 9 minutes long, opens with some closeup shots of voracious animals in action, including caterpillars that munch insatiably and blood-sucking leeches. It then stars a vampire bat feasting on the blood of a compliant guinea pig (see picture).

The bat, accompanied by Ellington's jaunty Echoes of the Jungle, unconsciously overacts in a way that would suit the most lurid of horror films - a parallel drawn in Painlevé's film by some short clips from F. W. Murnau's silent film Nosferatu (1922). Murnau's dark masterpiece of expressionist cinema, based on Bram Stoker's Dracula, had precociously used microphotography to portray a 'vampire polyp'.

Composed during the Second World War, The Vampire served as an allegory of Nazism. The implication is that Hitler's fascism infects the mind just as rabies from the blood-sucking bat infects the bodies of its victims.

Nature 'red in tooth and claw' has traditionally provided a source of drama for artists. The nature revealed by film in general - and by the underwater camera, time-lapse and micro-photography in particular - provided the alert surrealists with a disturbing vocabulary of form and motion that was well matched to their purposes.

Martin Kemp is professor of the history of art at the University of Oxford, Oxford OX1 1PT, UK. His latest book, Seen | Unseen, is published by Oxford University Press. 